\title{
FLOUTING MAXIM AND HEDGING MAXIM IN MULTICULTURAL STUDENTS INTERACTION
}

\author{
Maya Rizki Amalyasari'1), Ima Widiyanah ${ }^{2)}$ \\ IKIP Budi Utomo Malang \\ mayarizkiamalyasari@budiutomomalang.ac.id
}

\begin{abstract}
Abstrak
IKIP Budi Utomo as a private campus in the city of Malang has a composition of students from various tribes and cultures, making it a campus with a multi-cultural society. On this campus there are five tribes that dominate, they are: Javanese, Madurese, Dayaks, Sumba Flores, and Ambon. In multicultural societies, there are often obstacles, which in turn cause conflicts, in communication. A convention is needed between the speaker and the hearers so that communication becomes effective and efficient, and is able to minimize misunderstandings. In this case the concept called the principle of cooperation (Cooperative Principles) which is intended as a rule of communication in order to run effectively and efficiently becomes relevant to be studied. The design of this study is descriptive qualitative in which data sources obtained from dialogs that arise in daily interactions both between multicultural students and students and lecturers inside and outside the class at IKIP Budi Utomo Malang. In line with the results of the research analysis, it can be concluded that, of the 476 utterances recorded as raw data of this study, there were 45 cases of maxims flouts and 12 cases of maxims hedges, which formed a certain pattern in each multicultural students.
\end{abstract}

Keywords: Cooperation Principle, Maxims, Multicultural, Communication

CPendidikan Bahasa Inggris FPISH IKIP BU Malang

\section{Introduction}

Malang City as one of the largest Education cities in Indonesia is visited and inhabited by students from various regions in Indonesia. With these conditions Malang City can be said as a City with a multicultural society. One of the campuses in Malang is IKIP Budi Utomo where on this campus there are five dominant tribes, they are: Javanese, Madurese, Dayaks, Sumba Flores, and Ambon. Although there are no significant difficulties in terms of communication between students of different ethnic groups, the differences in customs and culture between students certainly lead to interesting situations to be observed, especially in language, when they interact both among themselves and with the professors who are majority on campus. from the Javanese tribe, where the students still have primordial regional ties which are still very strong.

In communicating, sometimes the hearers respond or give questions that are not appropriate or relevant to the problem intended by the speaker. In addition, there are also hearers who provide excessive responses or answers, provide incorrect information, and sometimes provide ambiguous information. That is a phenomenon that occurs in communication in the Association of Multicultural Students in Malang which often leads to misunderstandings to conflicts between different people.

In the above context, the Cooperative Principle (CP) introduced by H.P. Grice (1965) becomes relevant and important to study. In principle, PK is a rule of communication in order to run effectively and efficiently, which is able to minimize misunderstandings that can lead to conflict. Grice divides CP into four thimbles as follows: maxim of quantity, maxim of quality, maxim of relevance, and maxim of manner. Each thimble has sub-maxim which are 
detailed rules about what to do and what not to do in communication. CP violations usually result in communication failure, unless there is an implied intention contained in the speech of the speaker that is able to be well received by the hearers.

There are rules in communicating so that they can run well, effectively, and efficiently, known as the Cooperative Principle. This concept was first introduced by a British philosopher named H.P. Grice in his article entitled "Logic and Conversation" which he wrote in 1967. The essence of CP according to Black (2006) is "Make your conversational contributions such as is required, at the stage at which it occurs, by the accepted purpose or direction of the talk exchange in which you are engaged ", in communicating someone should contribute according to what is needed, both in terms of objectives and direction of communication. Grice divides the Cooperation Principle into four maxims, namely: maxim of quantity, maxim of quality, maxim of relevance, and maxim of manner.

\section{Maxim of Quantity}

Maxim of quantity requires each participant to contribute only as much or as much as needed by the hearers. In providing reasonable information, do not be too little and not too much, and contribute as needed. So, don't overdo it in giving information (Wijana, 1996; Rani, 2006; Darwowidjojo, 2003). This is consistent with what was stated by Grice via Griffiths (2006) and (Yule, 1996) follows. "Give appropriate amounts of information, not too little and not too much" (Grice via Griffiths, 2006). "Make your contribution as informative as is required" (Yule, 1996).

A: "Can anyone use this car park?"

B: "It's for customers of the supermarket." +> 'No'
In the conversation above, speaker B makes a slightly excessive contribution, if the parking lot in question is a public parking lot, in this context the phrase "It's for customers of the supermarket." It is not necessary. However, it is different if the parking lot in question is a parking area that is devoted to supermarket visitors. Although it violates the quantity maxim, by providing incomplete information, but there is an implicature that can be raised, you are not allowed to park your vehicle in this area because this parking lot is specifically for supermarket customers, while you are not a visitor.

\section{Maxim of Quality}

Renkema (2004) explains that the essence of this maxim is "try to make your contribution one that is true". This maxim requires the speaker to provide true information in a conversation, covering two aspects referred to by Grice (1991) as sub-maxims, namely: (1) do not say what you believe to be false "which means do not provide information that has not the truth is certain; (2) "do not say that for which you lack adequate evidence" means do not provide information that the speaker himself does not have enough evidence of the truth. Note the conversation snippet below quoted from Kroeger (2018)
A: Where does $C$ live?
B: Somewhere in the South of France.

It seems clear in the conversation above that speaker B violates the quality maxims, especially the second sub thimble. By giving an answer using the word 'somewhere', speaker B does not know for sure where the place of residence $\mathrm{C}$ is being discussed with certainty. 


\section{Maxim of Relevance}

This maxim requires the speaker to always make relevant contributions to the topic being discussed. The content of this maxim is according to Yule (1996) is "be relevant" which means described by Griffiths (2006) as a thimble that requires speakers to make relevant contributions in accordance with the current assumed goals of the people involved in the conversation. Relevant contributions are the essence of this maxim.

This maxim is also referred to by some scholars as the maxim of the relation, Birner (2012) argues that the term relation is more appropriate to refer to this maxim, because the utterance spoken must be related to the utterances before and after it. More broadly, utterance must be related and bound to the context inherent in the conversation, both textually and situationally.

A: I am out of petrol.

$\mathrm{B}$ : There is a garage around the corner.

The above conversation is very commonly used as an example of violation of relevance maxim. At first glance the answer B to utterance A seems irrelevant and indeed irrelevant, therefore violating the maxim of relevance. Tests $\mathrm{A}$ and $\mathrm{B}$ will be relevant if each speaker is able to grasp the implied / implicative intent of each utterance. The implied message that speaker A wants to convey is a question about where he can refuel for his vehicle. On the other hand, the implicature delivered by speaker B is that at the end of the road there is a workshop selling fuel. If these implicatures can be understood by all speakers the misunderstanding in the conversation can be avoided.

\section{Maxim of Manner}

"Be perspicuous!" (Easy to understand), is the super maxim of the maxim of the way. There are four aspects that are the focus of this maxim that is described in four sub-maxims, namely: Avoid obscurity of expression, avoid ambiguity, be brief (avoid unnecessary prolixity), be orderly (Grice, 1991; Yule, 1996; Renkema, 2004; Grundy, 2008; Birner, 2012; Senft, 2014; Kroeger, 2018).

A: How does this outfit look on me?

B: That's quite an outfit; I'm not sure I've seen you wear that before. The colors are certainly bright, and you're always looking good in bright colors, but then again it's awfully sunny outside and might call for something more muted ...

(Birner, 2012)

From the conversation above, it can be said that B violated the maxim of the way because he delivered his opinion in a long-winded manner. The implication that B wants to bring up is that you do not deserve to wear that shirt, but if $\mathrm{B}$ responds immediately by obeying this maxim, you look terrible, for example, not polite. Therefore, sometimes by considering politeness and other aspects, it would be wise if the speaker violates the maxim in the cooperative principle.

Based on the description above, the main objective of this study is to reveal how the patterns of flouting maxim and hedging maxim in the interaction between multicultural students are viewed from the framework of the Grice cooperative principle theory.

\section{Research Method}

This research is categorized as a descriptive qualitative research with dialogues that appear in daily interactions both between multicultural students and students and lecturers inside and outside the class at IKIP Budi 
Utomo Malang, as the data source. This research uses supporting instruments to collect and analyze data, such as: recording, observation, and interview. Data analysis was carried out with three stages of analysis, (1) data reduction was carried out using indicators made based on submaxim in the Grice cooperative principle, which is shown in the table below.

Table 1. Indicators Flouting and Hedging Maxim of Cooperation Principle

\begin{tabular}{llll}
\hline \multirow{2}{*}{ No. } & Maxim & \multicolumn{2}{c}{ Indicators } \\
\cline { 3 - 4 } & & \multicolumn{1}{c}{ Flouting } & \multicolumn{1}{c}{ Hedging } \\
\hline 1. & Quantity & 1. Excessive & Limited \\
\cline { 3 - 4 } & & 2. Less informative \\
\hline 2. & Quality & $\begin{array}{l}\text { 1. Untruthful (not } \\
\text { believed to be true) } \\
\text { 2. Unsupported by } \\
\text { adequate evidence. }\end{array}$ & $\begin{array}{l}\text { Lack } \\
\text { commitment of } \\
\text { the truth value }\end{array}$ \\
\hline 3. & Relevanc & Out of topic & Irrelevance \\
\hline e & Manner & 1. Obscurity & Obscure \\
\cline { 3 - 4 } & 2. Prolix & \\
\cline { 2 - 3 } & & 3. Disorderly & \\
\hline
\end{tabular}

(2) Data display is made in the form of tables to assist researchers in seeing the overall data obtained. Reduced data is analyzed in more depth which is then drawn (3) tentative conclusion about the pattern of violations and restrictions on the maxim of cooperative principle.

\section{Result and Discussion Result}

This session will discuss the results of the research, which starts with the data display of the research in the form of table.

Table 2. Data Display of Flouting Maxims and Hedging Maxims

\begin{tabular}{lcc}
\hline \multirow{2}{*}{ Maxims } & $\begin{array}{l}\text { Flouting } \\
\text { Maxims }\end{array}$ & $\begin{array}{l}\text { Hedging } \\
\text { Maxims }\end{array}$ \\
\cline { 2 - 3 } & Numbers & Numbers \\
\hline Quantity & 18 & 3 \\
\hline Quality & 11 & 6 \\
\hline Relevance & 10 & 3 \\
\hline Manner & 7 & 0 \\
\hline Total & 46 & 12 \\
\hline
\end{tabular}

The result shows that of the 476 utterances after being reduced based on indicators of flouts and hedges on the principle of Grice's cooperation (tables 1 ), there were 46 cases of flouting of maxim quantity; 11 cases of flouting quality maxim; 10 cases of flouting relevance maxim; and seven cases of flouting manner maxim. These cases are dominated by Javanese students with 23 cases out of a total of 154 utterances. Furthermore, there are 12 cases of hedging maxims distributed as follows: three cases of hedging quantity maxim; six cases of hedging quality maxim; three cases of hedging relevance maxim; and none of the student uses hedging manner maxim in their interactions. The details will be discussed in the next session.

\section{Discussion \\ Quantity Maxims: Flouting and Hedging}

From the table 2 it can be learnt that the violation of this maxim is dominate. The idea of maxim quantity is that a conversation requires each participant to contribute only as much or as much as needed by the hearers (Renkema, 2004). From 18 cases of flouting quantity maxim done by multicultural students, it draws three major patterns, they flout the maxim of quantity under certain circumstances, such as:

(a) They flout when they eager to emphasis their statements by giving a detail information with intention to make the hearer gets as clear as information about the topic being discussed. However, too much information can distract the hearer from the actual information they want to obtain, so it flouts the quantity maxim, which can be seen in this below conversation:

$\mathrm{F}$ : OK, are you from Malang? 
A : Yes I'm, born and live in Malang until now!"

Statement A, "born and live in Malang until now." It is not necessary in the above conversation fragment. By simply answering with "Yes, I'm" F should have understood what was meant by $\mathrm{A}$. the implicature that might arise from the violation was, A wanted to emphasize that A really comes from Malang City.

(b) They flout when they want to reject or deny certain information or offer by giving a detail reasons why they do not want to do these or those. The example of the flout can be seen in this below conversation:

\section{D : Don't you eat, Mas?}

M : I have eaten my breakfast. If I eat outside a lot, it will be more wasteful. I was already had a plan to not to be too wasteful, it turns out it's still wasteful. That was my first semester Jai, fifty thousand enough for three days snacks. Now it's just for one day.

M Statement in answering question $\mathrm{D}$, based on indicators from this study, violates three maxims at once, namely: quantity, relevance, and method. $\mathrm{M}$ wants to reject D's invitation to eat by giving a lengthy explanation, which in essence $M$ wants to save money. Of course, by answering "I had eaten this morning" was enough and completely answered D.'s invitation. However, M prefers to express his refusal in an indirect way to show his modesty to D.

(c) They flout when they are in a situation in which they have a same background of knowledge. Violation of the quantity maxim with the second indicator, less informative, there are two cases. Both occur if in the conversation both the speaker and the hearers have the same reference and the right presupposition. Such as the mention of addresses, shops, and so on by using terms that they both know. The following fragment of the conversation shows this pattern:

\section{F : Gramed is too expensive!}

Gramed is the shortening version of Gramedia, known as a book store with a very complete collection of books but little bit expensive in pricing.

Moreover, there three cases of hedging quantity maxim in this research. The hedging cases arise when the speaker wants to give the impression to the hearer that the information provided may not be complete enough.

A : where have you been going?

$\mathrm{M}$ : Wow, there are so many places, $\mathrm{Na}$ !

From the discussion above, it appears that $\mathrm{M}$ is restricting the information that is to be conveyed. By saying "there are so many places", M gives an answer in the form of an estimation, which means $M$ does not want to give details of information that might be desired by A.

\section{Quality Maxim: Flouting and Hedging}

Maxim of quality demands speaker to give contribution in an interaction as true as possible and do no say something that lack of adequate evidence (Griffiths, 2006). The results of the research show that from 476 utterances recorded, there are 11 cases of flouting quality maxim done by multicultural students.

The patterns arise from those cases are: guessing when they were not sure of the information conveyed, small talk of politeness, and circumambulation.

(a) They flout quality maxim when they guessed something because they were 
not sure of the information conveyed.

F: That is in the Church, but we also have a custom if in my area, it is in Lembata, Belis, using ivory.

A: Is it a kind of cloth?

The speaker tries to guess about Bellis mentioned by F. Implications: A is not sure what Bellis is.

(b) The pattern formed which violates the second indicator, unsupported by adequate evidence, usually used for small talk of politeness, as in the following case:

W: Dek, Sul, everyone, let's eat!

M: You're so bland! How if they all eat? $\mathrm{W}$ : All you have to do is order.

W only made small talk for courtesy by offering his hearers a meal. Small talk about Javanese courtesy is common, given the strong nature of Javanese customs that influences the behavior of the community, many considerations are taken when speaking, all of which boils down to the feelings of the hearers.

(c) Circumambulation sometimes makes speakers lie in a number of conditions. Typically, someone who is good at the art of rhetoric will be very easy to play the words without saying lies in a conversation. However, it is not uncommon when there is no room for circumambulation, because all the corroboration evidence is clear, lying becomes the last resort to be carried out, to defend the argument and its position in the conversation. Lying is categorized as providing information that does not correspond to reality which is an indicator of violation of quality maxims.

$\mathrm{U}$ : Wait, if you are asked, what say you? A: That's my friend
Ar: Who? then what is the relationship with me, what is the connection, how come it has to do with me? What's the answer?

A: (laughing)

A who feels cornered by U's question and tries to get around with a little lie by answering "that's my friend", a spontaneous answer in self-defense. A knows exactly that what he has done is wrong.

Furthermore, there are six cases of hedging quality maxim found in this research. The idea of hedging quality maxim is that the speaker is not responsible for the truth of his words. For example:

F: Yes, they say it's delicious but I've never tried it.

From the statement above, by saying "they say" F wants to say that she is not committed to the truth of the information she will convey. That is, the information she conveyed was not purely from her but someone else.

\section{Maxim of Relevance: Flouting and Hedging}

Relevance maxim focuses on relevant contributions according to the current assumed goals of the people involved in the conversation. In other words, the relevant contribution to the topic under discussion is the essence of this maxim. This maxim has one submaxim, which is be relevant! therefore, violation indicators used are off topic (Grundy, 2008).

In this study there were ten cases of violations of these maxims, which were dominated by the utterances of Javanese, Sumba, and Madura students. Violations of the relevance maxim done by multicultural students generally have an affirmative pattern on the statement 
or opinion of the speech partner, such as:

M: Just Class A, they aim to go strolling there partly, not want to ...

D: Sure they do emm, who doesn't know college kids.

M, who explained about a campus program that took place in Surabaya. M is of the opinion that his friends who take part in the program have a different agenda, namely to take a walk instead of prioritizing their apprenticeship duties. This opinion was agreed by $\mathrm{D}$, but not directly but with an irrelevant statement.

In addition, hedging of relevance maxim, which focuses on changing the topic of conversation without offending the speech partners, this is usually done indirectly. The following are examples of limitations on the maxim of relevance that Makassar students do:

$\mathrm{R}$ : Yes, that was not included into the cost to Pontianak yet, I just went to travel again until I got home

A: geez, hmm I'm confused what I want to say

A: Do you like it or not, live in Malang?

From the piece of conversation above, A tries to open a new topic by saying the utterances are italicized.

\section{Maxim of Manner: Flouting and Hedging}

The idea of manner maxim is that in a conversation, the speaker should avoid unclear expressions, avoid ambiguity, be brief, be orderly in giving statements (Kroeger, 2018).

In this study, there are seven cases of flouts of the manner maxim found which are dominated by prolix utterances. The implicatures of the flouts are vary, but all have the same goal in order to keep the conversation going longer, as in the example below:
A: Do you like it or not, live in Malang

M: Like it or not, just live it already, it's an obligation, for example, if we don't like it, just keep doing it, but if I personally like it, there are really many friends here.

However, in this research, there are no cases of hedging of the maxim of manner, this was possible because of the limited data obtained.

\section{Conclusion}

Of the 476 utterances recorded as raw data from this study, there were 45 cases of maximal violations and 12 cases of maximal restriction, which from here formed a certain pattern for each multicultural student as follows: a) Flouting of the Quantity Maxim by multicultural students is patterned: emphasis, denial, and in situations where both the speaker and the speech partner have the same reference and the right presupposition; b) Flouting of the Quality Maxim has the following pattern: Guess what they are because they are not sure of the information conveyed, lip service to politeness, keeping the rhythm of the conversation, and circumventing; c) Flouting of the Relevance Maxim in this study is patterned as: affirmation of the statement or opinion of the speech partner; d) Flouting of the Manner Maxim is patterned as: keep the conversation going longer; e) Hedging of the Quantity Maxim is Patterned as: gives the impression to the speech partner that the information provided may not be sufficiently complete; f) Hedging of the Quality Maxim is Patterned as: the speaker is not responsible for the truth of his words; g) Hedging of the Relevance Maxim is Patterned as: change the topic of conversation without offending the speech partner; h) However, in this study, there was no means of limiting the Maximum Method due to the limited 
data obtained.

\section{References}

Black, E. (2006). Pragmatic Stylistics. Edinburgh: Edinburgh University Press.

Birner, B., J. (2013). Introduction to Pragmatics. Wiley-Blackwell.

Brown, P. \& Levinson, S.C. (1990). Politeness. Some Universals in Language Usage. Cambridge: Cambridge University Press.

Chaer, A. (2007). Kajian Bahasa. Jakarta: Rineka Cipta.

Dardjowijojo, S. (2005). Psikolinguistik: Sebuah Perspektif Multidisipliner. Yogyakarta: Yayasan Obor Indonesia.

Grice, H.P. (1991). Studies in the Way of Words. Harvard University Press.

Griffiths, P. (2006). An Introduction to English Semantics and Pragmatics. Edinburgh University Press.

Grundy, P. (2008). Doing Pragmatics. Routledge.

Kroeger, P. R. (2018). Analyzing Meaning: An Introduction to Semantics and Pragmatics. Language Science Press.

Miles, M. \& Huberman, M. (1994). Qualitative Data Analysis: An Expanded Sourcebook. Beverly Hills: SAGE Publication Inc.

Renkema, J. (2004). Introduction to Discourse Studies. Philadelphia, PA, USA: John Benjamins Publishing Company.

Rani, A. (2006). Analisis Wacana. Malang: Bayumedia.

Senft, G. (2014). Understanding Pragmatics. Routledge.

Wijana, I. (1996). Dasar-dasar Pragmatik. Yogyakarta: ANDI.

Yule, G. (1996). Pragmatics. Oxford

University Press 